\title{
INVESTIGATION OF HYDROCHEMICAL DYNAMICS OF GROUNDWATER IN COASTAL BLOCKS OF TIRUVALLUR DISTRICT, TAMILNADU, INDIA
}

\author{
GEETHA S *AND DHARMENDIRA KUMAR M \\ Department of Applied Science and Technology, AC Tech, Anna University, Chennai.
}

\begin{abstract}
This paper presents the behaviour of cation and anion in samples of water collected from the coastal blocks of Tiruvallur District, Tamilnadu, India. 13 physiochemical parameters are investigated on the uniformly collected groundwater samples. It is revealed that fifty percentage of groundwater samples surpassed water quality levels pertaining to drinking and irrigation. In this investigation, descriptive statistical analysis is performed to understand groundwater characteristics. The hydro-chemical dynamics of groundwater are evaluated using graphical plots Piper, Wilcox, and Gibbs. Through the Piper plot, it is concluded that high concentrations of sodium would induce cation exchange between $\mathrm{Ca}^{2+}$ and $\mathrm{Mg}^{2+}$ from the soil. This may lead to the acceleration of air and water circulation through the soil in wet conditions. The inference of the Piper plot is supported by end result of Gibbs plot. Gibbs plot indicates evaporation dominance of anthropogenic activities, while Wilcox plot clearly indicates groundwater's suitability for irrigation purposes. Moreover, the cation concentration is seen to be high on the eastern portion of the chosen area. The level of groundwater treatment should be adequately determined for potable purposes and for agricultural purposes as the study concludes the intrusion of saline water, rock water interaction and irrigation flows.
\end{abstract}

Keywords: Anion and Cation, Gibbs, Groundwater quality, Physiochemical parameters, Piper, Wilcox.

\section{INTRODUCTION}

Water is the elixir of life. The dynamism of Hydrogeochemical processes governs the viability of potable water and agriculture. The chemistry of ground water is a significant factor in determining its utility in various applications. The groundwater chemistry is strongly determined by groundwater interaction with the minerals in the aquifer from which it flows. As a consequence, tracking and evaluation have become increasingly necessary in recent years [1-2]. The growing population put a stress on both land and groundwater. Depletion of groundwater is majorly because of geogenic and anthropogenic activities [3] An acute scarcity of surface water has led to a rising demand of groundwater supplies. Because of increased anthropogenic exploitation, the world's water supplies' quality is declining [4]. The disturbances due to anthropogenic activities and the action of natural processes like geological formation, dissolution of minerals, infiltration rate, recharge water quality leads to the deliverance of contaminants which inturn makes the groundwater vulnerable to contamination [5-6]. In developing countries', the outcome of increasing climate extremes like droughts and floods, socioeconomic and technological developments affect the usage and quality of water resources [7].

Commonly Groundwater contains dissolved mineral ions which lower the quality of water and its versatility for various purposes [8-9]. The standards for different usage is variable [10]. Hence the range of groundwater suitability for which it is abstracted necessitates its determination. Drinking water standards is focused in particular as it jeopardizes people health [11-12]. The restoration of the quality of groundwater after pollution is difficult and it normally takes a long time to return to its natural state. Groundwater quality monitoring in a region is done regularly to identify areas with possible environmental health issues [13]. The foundation for scientific groundwater resource management is hydro chemical studies [1]. The categorization of groundwater with regard to geochemical types is a vital part of scientific groundwater resource management since it allows for the monitoring of groundwater quality in an aquifer and the identification of recharge areas. Furthermore, composition of parent rock form and the overlying rock form affect the geochemistry of groundwater. Understanding water's chemical content is critical for assessing its utility in residential, commercial, and agricultural settings [14].

The interpretation and categorization of groundwater chemistry through various methods are done and the potability of groundwater is well documented $[4,15]$. Various geo-statistical definitions are employed to analyse complex data sets, allowing for a deeper understanding of water quality parameters. Identifying the threat allied with a specific event, action, or situation, and assessing the likelihood of that hazard occurring, is the progression of risk assessment. Hence, determining the amount and quality of groundwater is pertinent for advancing humanity and creating a database for potential water resource production strategies [16]. Presentation of chemical analysis in graphical form makes the understanding of complex groundwater systems simpler and quicker [13-16]. The Piper diagram portrays the hydro chemical regime in terms of cations and anions. Sequential statistical methods are used in multivariate data analyses [17]. Groundwater contamination of aquifers occurs as an effect of agricultural activity and urbanisation. Human health is harmed when the concentration of several inorganic and organic compounds exceeds the permissible range. Growing demand for potable water and maximization of long-term usage of groundwater necessitates evaluation of quality of groundwater [18]. This analysis aimed to characterize hydrogeochemical processes using graphical representations and multivariate statistical techniques to understand groundwater chemistry better.

\section{EXPERIMENTAL}

\subsection{Study Area}

The study area includes the coastal blocks, Minjur, Sholavaram and Puzhal of Tiruvallur District on Tamil Nadu's east coast. (Figure 1). It ranges $80^{\circ} 09^{\prime}$ to $80^{\circ} 18^{\prime}$ East and $13^{\circ} 10^{\prime}$ to $13^{\circ} 26^{\prime}$ North on a geographical scale encompassing a total area of $849.05 \mathrm{Km}^{2}$. The tool used to map and locate sampling points in study area was Arc GIS version 10. With an annual rainfall of $1,200 \mathrm{~mm}$, the north-eastern monsoon is the main rainmaker in the study area. This place has a tropical climate, with average annual temperatures of $24.3^{\circ} \mathrm{C}-32.9^{\circ} \mathrm{C}$ [19]. The humidity level is normally between 65 and 84 percent. Sedimentary formations, Archean rocks and Proterozoic rocks, dominate the landscape. High Gondwana, made of sand and silts, quaternary sand, and tertiary formations, is the most significant geological formation occurring at the coastal region. The coastal alluvium is covered in most of the study region, and Laterite deposits are found in definite locations [20]. The Monsoon Rivers, such as Araniyar, Korattalayar, Cooum, Nagari, and Nandhi, are important rivers with a dendritic drainage pattern [21]. The Aranyiar- Korattalayar and Cooum sub-basins flow eastward through the Tiruvallur District. The majority of agriculture production is reliant on groundwater in Sholavaram Block. The only natural resource of potable water is the urban aquifer for all the coastal blocks in the study region. Groundwater is often regarded as having less value for the drinking water supply, resulting in a drinking water shortage crisis, increased emissions and reduced potability [22]. 

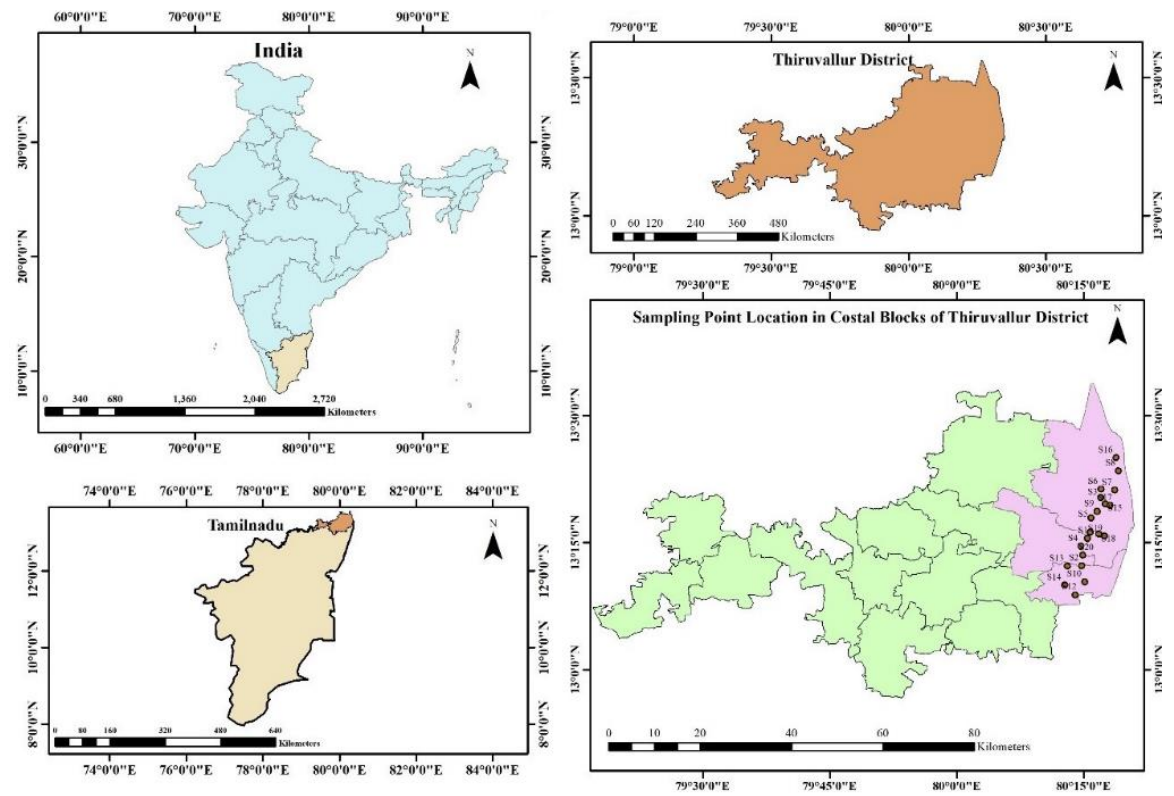

Figure 1. Location Map of Study Area.

Based on a good investigation survey, twenty sampling spots are chosen for collecting groundwater samples along the littoral area of the Tiruvallur District during post monsoon period of the year 2019. Hand-held Global Positioning System (GPS) is a conventional way to locate the latitude and longitude of the sampling points (Figure1). The American Public Health Association developed standard procedures for collecting, storing, and analysing major ions in watersamples [23]. For the ion analysis, the samples are collected in polythene bottles [24-25]. The ionic constituents such as Calcium $\left(\mathrm{Ca}^{2+}\right)$, Magnesium $\left(\mathrm{Mg}^{2+}\right)$, Sodium $\left(\mathrm{Na}^{+}\right)$, Potassium $\left(\mathrm{K}^{+}\right)$, Chlorides $\left(\mathrm{Cl}^{-}\right)$, Carbonates $\left(\mathrm{CO}_{3}{ }^{2-}\right)$, Bicarbonates $\left(\mathrm{HCO}_{3}{ }^{-}\right)$, Sulphates $\left(\mathrm{SO}_{4}{ }^{2-}\right)$, Total Nitrates $\left(\mathrm{NO}_{2}{ }^{-}+\mathrm{NO}_{3}{ }^{-}\right)$, Fluorides $\left(\mathrm{F}^{-}\right)$and Total dissolved solids (TDS) as well as the non-ionic constituents like $\mathrm{pH}$ and Electrical conductivity (EC) are determined in the collected samples. Major anions such as $\left(\mathrm{F}^{-}, \mathrm{NO}_{2}{ }^{-}+\mathrm{NO}_{3}{ }^{-}, \mathrm{SO}_{4}{ }^{2-}\right.$ are analyzed using spectrophotometer. $\mathrm{Na}^{+}$ and $\mathrm{K}^{+}$are analyzed by flame photometer (CL410). The concentrations of $\mathrm{Ca}^{2+}$,
$\mathrm{Mg}^{2+}, \mathrm{Cl}^{-}, \mathrm{CO}_{3}{ }^{2}$, and $\mathrm{HCO}_{3}{ }^{-}$are measured by titration. Portable meters $(\mathrm{HM}$ Digital COM-60) are employed to test the Electrical Conductivity (EC), $\mathrm{pH}$, and Total Dissolved Solids (TDS) immediately at the sampling site. The obtained results are compared to World Health Organization (WHO 2011) [26] and Bureau of Indian Standards (BIS- IS10500-2012) [27] recommended quality values (Table.1). The analytical data is used to classify water for utilitarian purposes and ascertain various factors that depend on which the chemical characteristics of water. The researchers analysed association among major ionic contents for a better understanding of hydro-chemical processes [28-29]. On a Piper- trilinear plot and a Wilcox plot [30], the hydro chemical results are measured and plotted using Diagrammes (version 6.75). Gibbs diagram helps in evaluating quality control mechanism and hydro-geochemical facies of the coastal blocks of the study area.

Table 1: Descriptive statistics of the physiochemical parameters.

\begin{tabular}{|c|c|c|c|c|c|c|c|}
\hline Parameter & Mean & Minimum & Maximum & $\begin{array}{l}\text { Standard } \\
\text { Deviation }\end{array}$ & $\begin{array}{l}\text { BIS Standards } \\
\text { (IS10500-2012) }\end{array}$ & $\begin{array}{c}\text { WHO } \\
\text { Standards (2011) }\end{array}$ & $\begin{array}{l}\text { Percentage of Samples } \\
\text { exceeding the limit }\end{array}$ \\
\hline $\mathrm{pH}$ & 7.94 & 7.4 & 8.4 & 0.27 & $6.5-8.5$ & $6.5-8.5$ & 0 \\
\hline Electrical Conductivity $(\mu \mathrm{S} / \mathrm{cm})$ & 1929.00 & 540.00 & 4200.00 & 1086.68 & - & 1500 & 50 \\
\hline TDS (mg/L) & 1320.95 & 329.50 & 2508.00 & 651.39 & 500 & 500 & 100 \\
\hline Calcium (mg/L) & 78.95 & 31.00 & 157.00 & 31.05 & 75 & 75 & 50 \\
\hline Magnesium (mg/L) & 57.78 & 6.00 & 157.00 & 41.73 & 30 & 50 & 50 \\
\hline Sodium $(\mathrm{mg} / \mathrm{L})$ & 288.30 & 7.00 & 580.00 & 198.97 & 200 & 200 & 50 \\
\hline Potassium $(\mathrm{mg} / \mathrm{L})$ & 26.55 & 3.00 & 81.00 & 18.38 & 12 & 10 & 75 \\
\hline Carbonates $(\mathrm{mg} / \mathrm{L})$ & 3.83 & 0.00 & 75.00 & 16.76 & - & - & 0 \\
\hline Bicarbonates $(\mathrm{mg} / \mathrm{L})$ & 342.55 & 136.00 & 825.00 & 159.68 & - & 300 & 60 \\
\hline Chlorides (mg/L) & 415.20 & 30.00 & 1120.00 & 299.04 & 250 & 200 & 60 \\
\hline Sulphates $(\mathrm{mg} / \mathrm{L})$ & 107.80 & 10.00 & 380.00 & 100.41 & 200 & 400 & 0 \\
\hline Total Nitrates $(\mathrm{mg} / \mathrm{L})$ & 24.60 & 2.00 & 92.00 & 26.23 & 45 & 45 & 15 \\
\hline Fluorides $(\mathrm{mg} / \mathrm{L})$ & 0.56 & 0.00 & 1.80 & 0.49 & 1 & 1.5 & 15 \\
\hline
\end{tabular}

\section{RESULT AND DISCUSSION}

\subsection{Physio-chemical characteristics}

The groundwater's chemical characteristics in addition with $\mathrm{pH}, \mathrm{EC}$, and TDS are statistically analysed with Microsoft Excel 2007. The result obtained is compared with BIS (2012) and WHO (2011) standards (Table 1). The pH value ranges from 7.4 to 8.4 and has a mean 7.94 , corroborating the alkalinity of the groundwater. The EC value is between 540 to $4200 \mu \mathrm{S} / \mathrm{cm}$ showing an increasing trend along the groundwater flow direction. The TDS values vary between 329 to $2508 \mathrm{mg} / \mathrm{L}$ with a mean value of $1320 \mathrm{mg} / \mathrm{L}$. More than half the samples exceed the maximum allowable value of $1500 \mathrm{mg} / \mathrm{L}$ prescribed by standards.
The inter-relationship between variables is clearly indicated (Table 1) through statistical parameters to the same degree of mean and standard deviation. This possibly opens a new plethora of knowledge and research, reducing uncertainty in decision making as well as helps in understanding causal relationships. TDS is more than $1000 \mathrm{mg} / \mathrm{L}$ (Table 2) for a majority of groundwater samples rendering it saline and hence unfit for consumption. In the cationic chemistry, the minimum concentrations of $\mathrm{Ca}^{2+}, \mathrm{Na}^{+}, \mathrm{Mg}^{2+}$, and $\mathrm{K}^{+}$are $31,7,6$, and $3 \mathrm{mg} / \mathrm{L}$, and the maximum concentrations are $157,580,157$, and $81 \mathrm{mg} / \mathrm{L}$, respectively. The averages of these cations are $78,288,57$, and 26 , respectively. The sequence of prevalence of these cations $\mathrm{K}^{+}>\mathrm{Na}^{+}>\mathrm{Ca}^{2+}>\mathrm{Mg}^{2+}$. The concentration of carbonate ions is in traces, and the bicarbonate concentrations are considerable 
in all water samples analysed. The evident of chloride anions in the vicinity of 30 to $1120 \mathrm{mg} / \mathrm{L}$ because of seawater intrusion. After chloride, the most dominating anion is bicarbonate. The anion such as bicarbonate, sulphate, nitrate, and fluoride vary from 136 to 825,10 to 380,2 to 92 , and 0 to 1.8 , respectively. Dominance of anions is in the following order: $\mathrm{Cl}^{-}>\mathrm{HCO}_{3}>\mathrm{SO}_{4}{ }^{-}>\left(\mathrm{NO}_{2}+\mathrm{NO}_{3}\right)$. A high chloride concentration (620 to $1120 \mathrm{mg} / \mathrm{L}$ ) is observed from the groundwater samples $2,5,8,11,18$, and 19 , which contributes around $60 \%$ of anionic concentration due to an influence of poor sanitary conditions, chemical fertilizers, irrigation return flow, and industrial discharges. According to WHO (2011), the maximum permissible limit of chloride value is $250 \mathrm{mg} / \mathrm{L}$. Out of 20 samples, 12 samples are unfit for drinking as they exceed permissible limits. A close scrutiny of sodium and chloride ions, have a broader range of distributions and a higher standard deviation. This advocates a possible intrusion of neighbouring saline water, which has a comparatively high sodium and chloride concentration. The $\mathrm{K}^{+}$concentration is high in most of the sampling spots, may be because of groundwater interaction with the rock, leading to the cation exchange. Likewise, the excess presence of potassium and sodium may be because of surplus use of Chemical fertilizers in the agriculture area and irrigation return flow. Bicarbonate is an important tool for studying the applicability of irrigation water. The samples encounter bicarbonates ranged from $136.00 \mathrm{mg} / \mathrm{L}$ to $825.00 \mathrm{mg} / \mathrm{L}$ and a mean of $342.55 \mathrm{mg} / \mathrm{L}$.

Table 2: Ground water categorization related to TDS [31].

\begin{tabular}{|c|c|c|c|c|c|}
\hline S.No & Groundwater class & TDS Range $(\mathbf{m g} / \mathbf{L})$ & No. of Samples & Percentage of Samples & Sample Number \\
\hline 1 & Fresh water & $<1000$ & 8 & 40 & $3,4,6,7,13,14,17,20$ \\
\hline 2 & Slightly Saline & $1000-3000$ & 12 & 60 & $1,2,5,8,9,10,11,12,15,16,18,19$ \\
\hline 3 & Moderately Saline & $3000-10000$ & 0 & 0 & - \\
\hline 4 & Very Saline & $10000-30000$ & 0 & 0 & - \\
\hline 5 & Brine & $>30000$ & 0 & 0 & - \\
\hline
\end{tabular}

The measured cations and anions are indicated (Table 3). The interference of the anion and cation is prevalent in the sampling spots S12, S13 due to overexploitation of groundwater from the aquifer and less recharge rate. The over-exploitation of groundwater from the aquifer for the samples S2, S3, S6, S8, S9, S10, S11, S15, S16, S17, S18, S19, S20 is moderate.

Table 3: Anions and Cations values in meq/L.

\begin{tabular}{|c|c|c|c|c|c|c|c|c|c|c|}
\hline $\begin{array}{c}\text { Sample } \\
\text { Number }\end{array}$ & $\mathrm{Ca}^{2+}$ & $\mathbf{M g}^{2+}$ & $\mathbf{N a}^{+}$ & $\mathbf{K}^{+}$ & $\mathrm{Cl}^{-}$ & $\mathrm{CO}_{3}^{-}$ & $\mathrm{HCO}_{3}^{-}$ & $\mathrm{SO}_{4}{ }^{2-}$ & $\begin{array}{c}\text { Total Cations } \\
\text { (meq/L) }\end{array}$ & $\begin{array}{c}\text { Total Anions } \\
\text { (meq/L) }\end{array}$ \\
\hline S1 & 3.90 & 4.42 & 6.65 & 0.82 & 10.39 & 0.00 & 4.59 & 2.04 & 15.79 & 17.03 \\
\hline S2 & 4.10 & 5.17 & 21.65 & 0.72 & 17.98 & 0.00 & 5.25 & 3.29 & 31.64 & 26.52 \\
\hline S3 & 3.40 & 4.00 & 3.83 & 0.15 & 3.93 & 0.00 & 4.02 & 0.21 & 11.38 & 8.16 \\
\hline S4 & 4.60 & 1.17 & 3.96 & 0.23 & 2.87 & 0.00 & 6.16 & 0.33 & 9.95 & 9.36 \\
\hline S5 & 7.00 & 10.00 & 25.13 & 0.18 & 31.46 & 0.00 & 2.67 & 7.92 & 42.31 & 42.05 \\
\hline S6 & 2.85 & 1.58 & 0.30 & 1.05 & 0.84 & 0.05 & 2.56 & 0.38 & 5.79 & 3.83 \\
\hline S7 & 2.70 & 1.50 & 6.87 & 0.38 & 4.27 & 0.00 & 6.52 & 0.35 & 11.45 & 11.15 \\
\hline S8 & 4.65 & 3.50 & 25.22 & 2.08 & 17.42 & 0.00 & 5.97 & 6.04 & 35.44 & 29.42 \\
\hline S9 & 3.20 & 1.75 & 20.65 & 0.54 & 15.03 & 2.50 & 3.61 & 3.33 & 26.14 & 24.47 \\
\hline S10 & 3.45 & 7.00 & 14.78 & 0.69 & 12.36 & 0.00 & 6.72 & 3.44 & 25.92 & 22.52 \\
\hline S11 & 5.70 & 4.96 & 21.52 & 0.49 & 17.42 & 0.00 & 7.16 & 3.96 & 32.67 & 28.54 \\
\hline S12 & 3.40 & 9.17 & 7.83 & 1.08 & 7.95 & 0.00 & 4.85 & 2.29 & 21.47 & 15.09 \\
\hline S13 & 4.30 & 13.08 & 3.30 & 0.74 & 4.72 & 0.00 & 2.77 & 3.50 & 21.43 & 10.99 \\
\hline S14 & 2.25 & 1.00 & 6.30 & 0.08 & 4.33 & 0.00 & 2.23 & 2.88 & 9.63 & 9.43 \\
\hline S15 & 1.55 & 4.92 & 24.78 & 0.95 & 16.43 & 0.00 & 13.52 & 1.58 & 32.20 & 31.54 \\
\hline S16 & 2.40 & 3.58 & 17.83 & 1.08 & 14.97 & 0.00 & 6.82 & 0.67 & 24.89 & 22.46 \\
\hline S17 & 4.15 & 3.67 & 5.22 & 1.00 & 5.34 & 0.00 & 6.51 & 0.90 & 14.03 & 12.74 \\
\hline S18 & 4.70 & 5.25 & 12.17 & 0.44 & 19.10 & 0.00 & 5.87 & 0.98 & 22.56 & 25.95 \\
\hline S19 & 7.85 & 10.08 & 19.13 & 0.79 & 24.86 & 0.00 & 9.39 & 0.46 & 37.86 & 34.71 \\
\hline S20 & 2.80 & 0.50 & 3.57 & 0.13 & 1.60 & 0.00 & 5.11 & 0.38 & 6.99 & 7.09 \\
\hline
\end{tabular}

\subsection{Multivariate Statistical analysis}

Most often environmental issues were solved using Multivariate Statistical strategies. Some of the methods practiced in water-quality data analysis were Correlation Analysis (CA), Principal Component Analysis (PCA) and Hierarchical Cluster Analysis (HCA) [31]. The statistical association between two or more variables was assessed using Pearson's correlation matrices [9]. The overall coherence of the data set was presented and the particular parameter participation in the hydrochemistry was determined [20]. Microsoft Excel 2007 was used for finding the correlation matrix for 13 parameters and values of the correlation coefficient were prescribed (Table 4). Poor correlation was indicated by a value of $<0.5$ and excellent correlation, by a value of $>0.5$. A strong correlation exists between $\mathrm{Cl}^{-}$with $\mathrm{Na}^{+}(0.876), \mathrm{Ca}^{2+}(0.626), \mathrm{EC}(0.965)$ and TDS (0.953) indicating the leaching of secondary salts, the contamination due to anthropogenic activities and reverse ion exchange. A good positive correlation between $\mathrm{EC}$ with $\mathrm{Na}^{+}(0.938)$, TDS (0.985), $\mathrm{Cl}^{-}(0.965)$ implies prevalence of ions in this region. The Major Elements like $\mathrm{Na}^{+}, \mathrm{Ca}^{2+}, \mathrm{Cl}^{-}$and $\mathrm{SO}_{4}{ }^{2-}$ are associated to TDS with high correlation coefficients $0.953,0.526,0.953,0.593$ respectively. Artificial agricultural fertilizers and saltwater intrusion are the major reasons for the ionic variance of the groundwater in the study area. 
Table 4: Pearson Correlation matrix of the study area

\begin{tabular}{|c|c|c|c|c|c|c|c|c|c|c|c|c|c|}
\hline & pH & EC & TDS & $\mathrm{Ca}^{2+}$ & $\mathbf{M g}^{2+}$ & $\mathrm{Na}^{+}$ & $\mathbf{K}^{+}$ & $\mathrm{CO}_{3}^{-}$ & $\mathrm{HCO}_{3}^{-}$ & $\mathrm{Cl}^{-}$ & $\mathrm{SO}_{4}{ }^{2-}$ & $\mathrm{NO}_{2}+\mathrm{NO}_{3}$ & $\mathbf{F}$ \\
\hline pH & 1.000 & & & & & & & & & & & & \\
\hline EC & 0.267 & 1.000 & & & & & & & & & & & \\
\hline TDS & 0.270 & 0.985 & 1.000 & & & & & & & & & & \\
\hline $\mathrm{Ca}^{2+}$ & 0.311 & 0.526 & 0.520 & 1.000 & & & & & & & & & \\
\hline $\mathbf{M g}^{2+}$ & 0.490 & 0.470 & 0.448 & 0.550 & 1.000 & & & & & & & & \\
\hline $\mathrm{Na}^{+}$ & 0.183 & 0.938 & 0.953 & 0.329 & 0.237 & 1.000 & & & & & & & \\
\hline $\mathbf{K}^{+}$ & -0.236 & 0.235 & 0.288 & -0.021 & 0.142 & 0.307 & 1.000 & & & & & & \\
\hline $\mathrm{CO}_{3}^{-}$ & 0.400 & 0.066 & 0.083 & -0.117 & -0.212 & 0.214 & -0.067 & 1.000 & & & & & \\
\hline $\mathrm{HCO}_{3}^{-}$ & 0.071 & 0.393 & 0.473 & -0.021 & 0.035 & 0.438 & 0.260 & -0.186 & 1.000 & & & & \\
\hline $\mathrm{Cl}^{-}$ & 0.288 & 0.965 & 0.953 & 0.626 & 0.472 & 0.876 & 0.148 & 0.088 & 0.287 & 1.000 & & & \\
\hline $\mathrm{SO}_{4}{ }^{2-}$ & 0.098 & 0.617 & 0.593 & 0.378 & 0.398 & 0.605 & 0.183 & 0.118 & -0.267 & 0.583 & 1.000 & & \\
\hline $\mathrm{NO}_{2}+\mathrm{NO}_{3}$ & -0.390 & 0.108 & 0.124 & 0.020 & 0.028 & 0.154 & 0.167 & -0.142 & 0.218 & 0.040 & 0.009 & 1.000 & \\
\hline $\mathbf{F}$ & -0.004 & 0.344 & 0.343 & 0.384 & 0.318 & 0.235 & 0.136 & -0.083 & 0.390 & 0.343 & -0.145 & 0.198 & 1.000 \\
\hline
\end{tabular}

\subsection{Hydrogeochemical Progression}

Scatter plots decrypt the ionic relation accountable for finding the water quality (Figures. 2,3,4, and 5). The balance relations among the dissolved ions are accustomed to check the origin of solutes [2,30-33]. The chemical data of water samples are plotted on $\mathrm{Na}^{+}$vs $\mathrm{Cl}^{-}$scatter plot. $\mathrm{Na}^{+} / \mathrm{Cl}^{-}$relationship helps to analyse how salinity and saline intrusions are acquired. Groundwater is most likely influenced by rock water contact, perhaps owing to the continuous

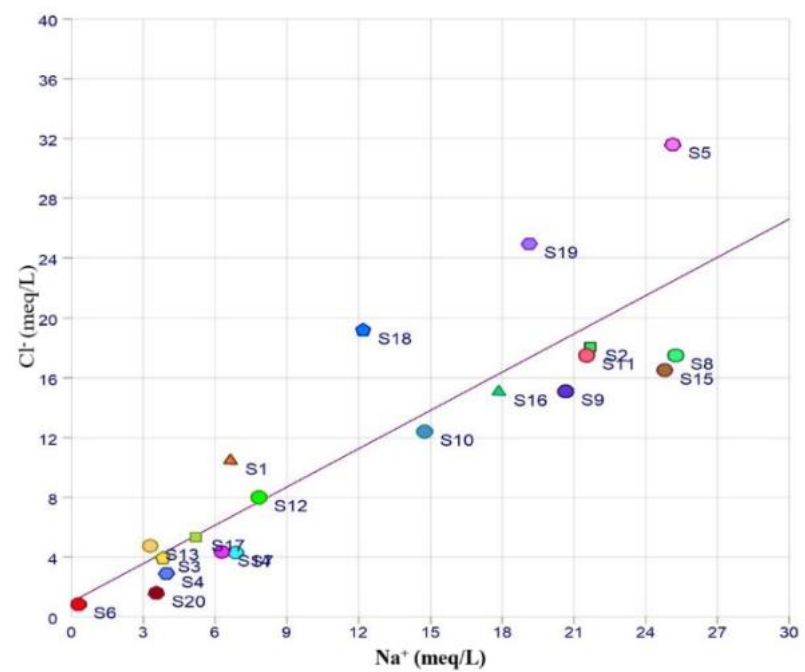

Figure 2. Scatter Plot showing the ionic relationship between $\mathrm{Na}^{+}$and $\mathrm{Cl}$

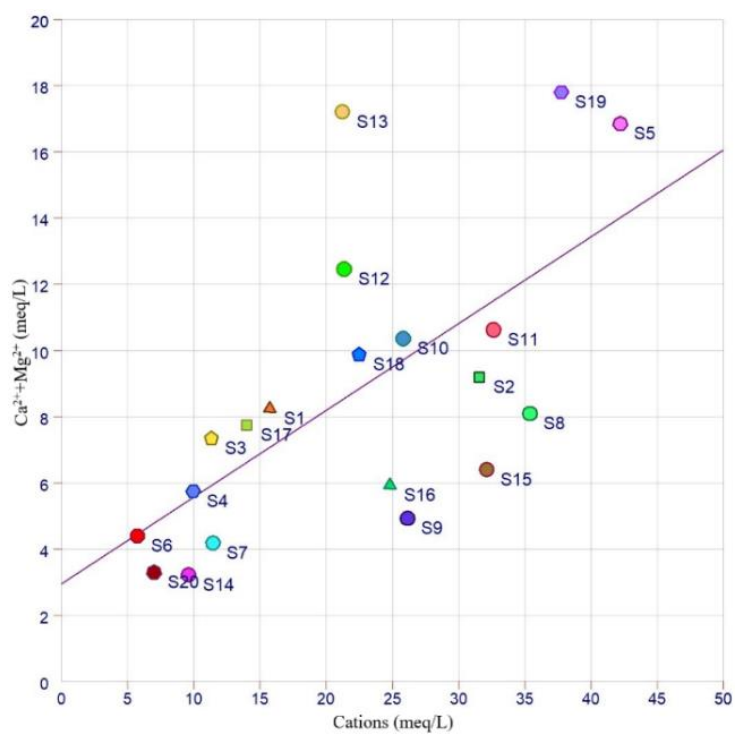

Figure 4. Relationship of $\mathrm{Ca}^{2+}+\mathrm{Mg}^{2+}$ vs Total cations. weathering of calcium-magnesium silicates, primarily from gypsum, calcite and feldspar (Figure 2).

An increased $\mathrm{HCO}_{3}{ }^{-}$concentration is plotted against $\mathrm{Na}^{+}$concentration in groundwater (Figure 3). $\mathrm{Na}^{+}$is having lesser correlation with $\mathrm{HCO}_{3}{ }^{-}$suggesting the occurrence of controlled silicate weathering. The relationships of $\mathrm{Ca}^{+}+\mathrm{Mg}^{+}$ versus $\mathrm{HCO}^{-}$, (Figure 4) are evidence of meticulous silicate weathering. Many sample points in the $\mathrm{Na}^{+}+\mathrm{K}^{+}$vs. total cations displayed good correlation in the ionic relationship diagram indicates the weathering of silicates (Figure 5).

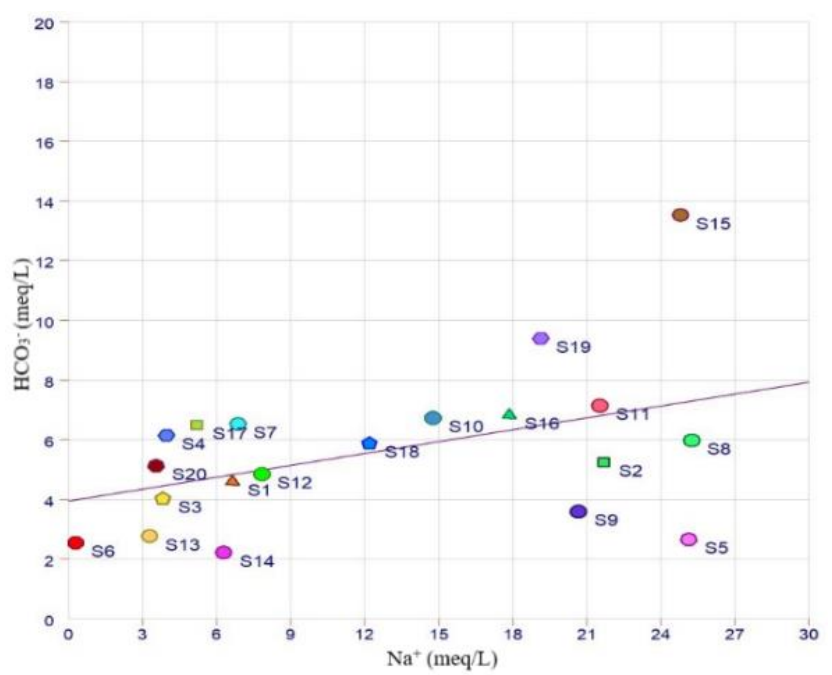

Figure 3. Scatter Plot showing the ionic relationship between $\mathrm{Na}^{+}$and $\mathrm{HCO}_{3}{ }^{-}$

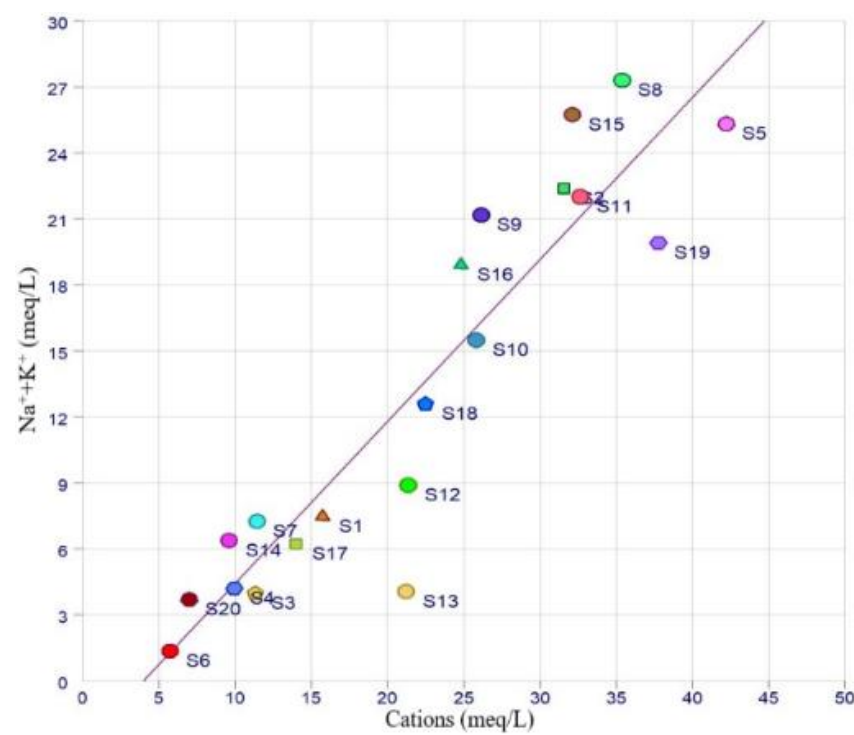

Figure 5. Relationship of $\mathrm{Na}^{+}+\mathrm{K}^{+}$vs Total cations. 


\subsection{Hydrochemical Classification}

The Evidence of finding the hydrochemical facies is chosen as a useful tool in assessing the water chemistry [12].

\subsubsection{Piper plot}

The hydrochemical facies of the groundwater can be inferred by plotting Piper trilinear diagram. These facies support in determining the origin and classification of water types. The basic water chemistry samples concerning the presence of some key cations like $\mathrm{Na}^{+}, \mathrm{Ca}^{2+}, \mathrm{K}^{+}, \mathrm{Mg}^{2+}$ also some chief anions like $\mathrm{HCO}_{3}{ }^{-}, \mathrm{CO}_{3}{ }^{2-}, \mathrm{Cl}^{-} \mathrm{SO}_{4}{ }^{2-}$ and their behavior are determined constructing Piper trilinear diagrams [34]. A Piper diagram comprises of a geometrical combination of two triangles outside and a diamond-shaped central quadrilateral. The left cations' triangle shows cations concentration in $\% \mathrm{mg} / \mathrm{L}$ while right anions' triangle shows that of anions. The resultant points from the cation and anion triangular plots are placed over the inner diamond-like quadrilateral structure $[2,30,35]$. The types of water are designated bestowing to the zones in which these points lie on the middle quadrilateral plot. Each point represents one water type [4]. Interpretation of hydro chemical data is accomplished by Piper diagram, which can show the chemical process of groundwater aiding in irrigation suitability and potable purposes. The values cations and anions in meq/L are imported in the triangular portion, and their total combinations are plotted in the grid. A Piper diagram is created for the coastal blocks of the Tiruvallur District utilizing the analytical data procured from the hydrochemical analysis (Figure 6).

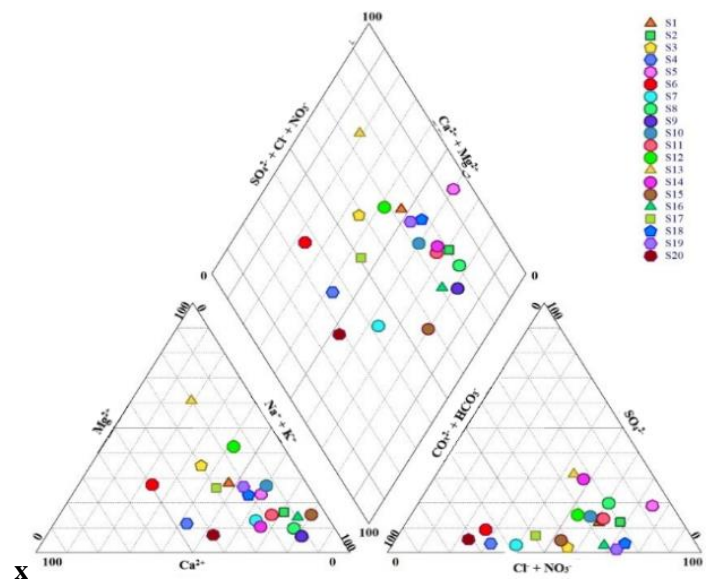

Figure 6. Piper Diagram showing Geochemical facies of Groundwater.

In general, we can classify the sample points in the Piper diagram into four fields. Field I represent $\mathrm{Ca}^{2+}-\mathrm{Mg}^{2+}-\mathrm{Cl}^{-}-\mathrm{SO}_{4}{ }^{2-}$ dominance. The samples $\mathrm{S} 1, \mathrm{~S} 3$, $\mathrm{S} 12, \mathrm{~S} 13$, and $\mathrm{S} 17$ fall on field I demonstrating the mild dominance of alkaline earth over alkali and strong acidic anion over weak acidic anions. Field II includes $\mathrm{Na}^{+}-\mathrm{K}^{+}-\mathrm{Cl}^{-}-\mathrm{SO}_{4}{ }^{2-}$ dominance. The samples $\mathrm{S} 2, \mathrm{~S} 5, \mathrm{~S} 8$, S9, S10, S11, $\mathrm{S} 14, \mathrm{~S} 15, \mathrm{~S} 16, \mathrm{~S} 18, \mathrm{~S} 19$ comes under the field II category. Field III contains $\mathrm{Na}^{+}-$ $\mathrm{K}^{+}-\mathrm{HCO}_{3}{ }^{-}$dominance. The samples S7and S20 are in field III grouping. Field IV contains $\mathrm{Ca}^{2+}-\mathrm{Mg}^{2+} \mathrm{HCO}_{3}{ }^{-}$dominance. The samples $\mathrm{S} 4$ and $\mathrm{S} 6$ come under field IV, indicating alkaline earth dominance over alkali and weak acidic anion over strong acidic anions. However, $\mathrm{Na}^{+}-\mathrm{Cl}^{-}$and $\mathrm{Ca}^{2+}-\mathrm{Na}^{+}-\mathrm{HCO}_{3}{ }^{-}$are the two major influenced water types in the domain from the grid. $\mathrm{Na}^{+}$is having acceptable correlation with $\mathrm{Cl}^{-}$and $\mathrm{SO}_{4}{ }^{2-}$ feasibly due to intrusion of saline water. $\mathrm{Na}^{+}$and $\mathrm{K}^{+}$are exchanged between the $\mathrm{Ca}^{2+}$ and $\mathrm{Mg}^{2+}$ from the solid aquifer matrix. This supports the argument that groundwater chemistry is pretentious by interchange of cations. Increased concentrations of sodium will induce cation substitution between $\mathrm{Ca}^{2+}$ and $\mathrm{Mg}^{2+}$ from the soil. This may develop the anaerobic condition in the soil and reduces the air- water circulation through the soil in wet conditions.

\subsubsection{Gibbs plot}

Gibbs plot is a common tool to decisive the relationship between water composition and lithological characteristics of aquifers [36]. The Gibbs plot has three fields: precipitation dominance, evaporation dominance, and rock-water contact dominance [13,36-37]. Samples S1, S2, S5, S8, S9, S10, S11, S12, S15, S16 and S19, experience evaporation superiority due to semi-arid environmental climate conditions and surface pollution sources, mainly excessive fertiliser usage, irrigation return flow, industrial outflows, and domestic discharges (Figure 7). Samples S3, S4, S6, S7, S13, S14, S17, S18 and S20 which fall under rock-water interaction zone showed that chemical weathering of rock-forming minerals affects groundwater quality through rock dissolution caused by water below the surface circulates. The groundwater chemical dynamics in the study area is predominantly controlled by complex geochemical mechanisms [14]. The sample outliers clearly indicate anthropogenic activities effects due to urbanisation.
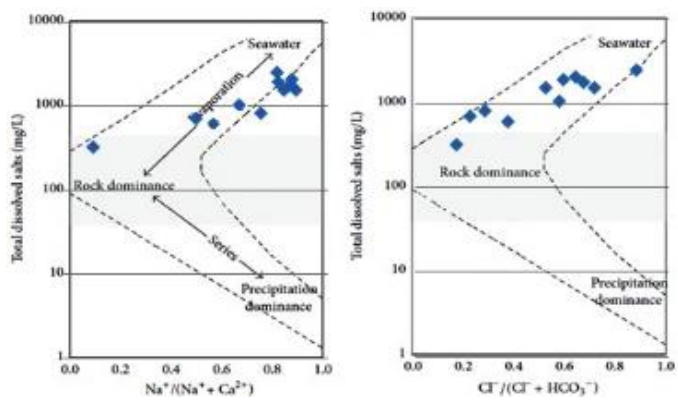

Figure 7. Gibbs plot revealing the Groundwater mechanism in the Study area.

\subsubsection{Wilcox Plot}

Sodium concentration helps in classifying water used for irrigation, because sodium concentration can reduce the soil permeability and soil structure [19]. The ionic concentration is represented in milliequivalents per litre in Wilcox diagram [38]. The $\mathrm{Na} \%$ concerning other cations that are existing in water helps in classifying it [31,39-40].

From the Wilcox diagram (Figure 8) it is seen that sample locations S4, S6, S20 lie under the excellent to the good category for irrigation activity. The sample locations S1, S3, S12, S13 are suitable for irrigation as they lie under good to permissible limits. The sample locations S7, S14 lies under the category of permissible limit to doubtful for agricultural purpose and S2, S5, S8, S15, S19 are unsuitable. However, only fifty percentage of the sample location lies under the excellent to the permissible limit for irrigation. Hence it is a critical alarming situation for groundwater quality.

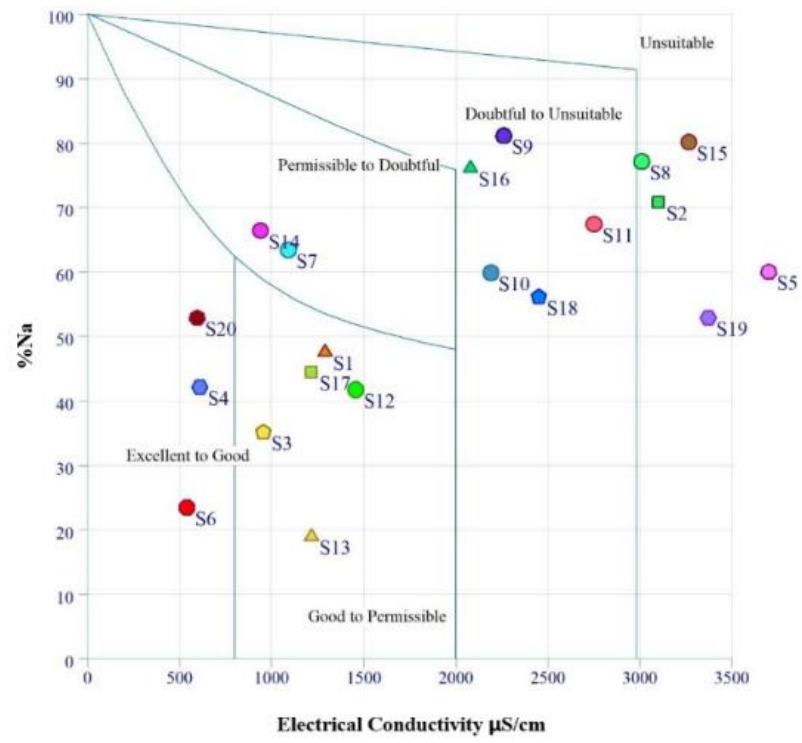

Figure 8. Wilcox plot.

\section{CONCLUSIONS}

Groundwater plays a major role in domestic front and agricultural front. In this investigation, the Piper plot assessed groundwater types. The high concentrations of $\mathrm{EC}, \mathrm{Cl}, \mathrm{Na}, \mathrm{Ca}$, and $\mathrm{Mg}$ in the research regions of coastal blocks of Tiruvallur District clearly demonstrate that the interaction of rock - water mechanism due to anthropogenic activities is predominant source of groundwater degradation. 
The majority of the samples fall in field II indicating $\mathrm{Na}^{+}-\mathrm{K}^{+}-\mathrm{Cl}^{-}-\mathrm{SO}_{4}{ }^{2-}$ dominance. The sequence of major ions in the study area is as follows: $\mathrm{Na}^{+}>\mathrm{Cl}^{-}$ $>\mathrm{HCO}_{3}{ }^{-}>\mathrm{Mg}^{2+}>\mathrm{Ca}^{2+}>\mathrm{SO}_{4}{ }^{-2}>\mathrm{K}^{+}>\mathrm{CO}_{3}{ }^{-}$. The main dominant ions of samples show the inter-correlation between these ions and its origin. The parameters like $\mathrm{Na}^{+}, \mathrm{Cl}^{-}, \mathrm{Ca}^{2+}, \mathrm{Mg}^{2+}, \mathrm{SO}_{4}{ }^{-2}$ show good positive correlation indicating the saltwater intrusion. The Wilcox diagram has assessed groundwater suitability for irrigation which reals the fact that groundwater chemistry ought to be monitored. The study concentrates on coastal blocks of Tiruvallur District where irrigation is practiced in Sholavaram block where the groundwater quality ranges from excellent to good. The major sampling stations in the study region are contained in the evaporation zone is signified by the Gibbs plot. The outcome of the Gibbs plot reveals that evaporation dominant on account of the dry and semi - arid condition persuade in the region. As groundwater interacts with reserves of aquifer and mixes with other groundwater sources along the subsurface flow path, it undergoes chemical changes. Integrated Water resources management plans are required in the study area for managing the groundwater quality degradation problem. This study would enable policy makers in efficient management of groundwater in coastal areas.

\section{ACKNOWLEDGMENTS}

The authors are grateful to the Department of Applied science and Technology, Anna University, Chennai for the laboratory Facilities.

\section{REFERENCES}

1. Senthilkumar S, Balasubramanian N, Gowtham B, Lawrence JF, Appl. Water Sci. 7, 263, (2017).

2. Kumar PJS. Elixir Geoscience,54,12208, (2013).

3. Fadiran AO, Dlamini SC, Mavuso A. Bull. Chem. Soc. Ethiop.22,197, (2008).

4. Ramesh K, Thirumangai V, Int J Eng Res Appl, 4,63, (2014).

5. Adnan S, Iqbal J, Maltamo M, Bacha MS, Shahab A, Valbuena R, Environments, 6, (2019).

6. Kassegne AB, Leta S. Cogent Environ. Sci.,6, (2020).

7. Bonetto SMR, Caselle C, de Luca DA, Lasagna M, Sustainability, 13,1 (2021).

8. Wagh VM, Panaskar DB, Jacobs JA, Mukate SV, Muley AA, Kadam AK. Arab. J. Geosci.12, (2019).

9. Kumar A, Singh CK, Water Qual Expo Health.7,373, (2015).

10. Gaikwad S, Gaikwad S, Meshram D, Wagh V, Kandekar A, Kadam A, Environ. Dev. Sustain. 22, 2591, (2020).

11. Brhane GK. Water Sci.32,213, (2018).

12. Ayadi Y, Mokadem N, Besser H, Environ. Earth Sci.77, (2018).

13. Ravikumar P, Somashekar RK, Prakash KL, Earth Sci., 80, (2015).

14. Venkateswaran S, Deepa S, Aquat. Procedia.4,1283, (2015).

15. Krishna Kumar S, Hari Babu S, Eswar Rao P, Appl.Water Sci,7,2533, (2017).

16. Vasanthavigar M, Srinivasamoorthy K, Vijayaragavan K, Environ. Monit. Assess.171,595, (2010).

17. Manoj K, Ghosh S, Padhy PK, Res. J. Chem. Sci.3,32, (2013).

18. Basavarajappa HT, Manjunatha MC, Aquat. Procedia.4,1354, (2015).

19. Sridhar SGD, Balasubramanian M, Jenefer S, Shanmugapriya P,Naveenkumar R, Ragunath P, J. Acad. ind. res. 5,161, (2017).

20. Sridhar SGD, Kanagaraj G, Rafik MM, Balasubramanian M., Appl. Water Sci. 7, 4651, (2015).

21. Krishna Kumar S, Bharani R, Magesh NS, Godson PS, Chandrasekar N, Appl Water Sci, 4, 341, (2014).

22. Rawat KS, Singh SK. Indones.J. Geogr.,51,78, (2019).

23. APHA A\& W. Standard Methods Nonalcoholic Beverages \&. Reagents and Standards as per Standard Methods for the Examination of Water and Wastewater, APHA AWWA WEF. (2014).

24. Mondal NC, Singh VP, Singh VS, Saxena VK. J. Hydrol. ,388, 100, (2010).

25. Rina K, Datta PS, Singh CK, Mukherjee S, Hydrol. Process, 26,1538, (2012).

26. Herschy RW, Encycl. Earth Sci. Ser. 876, (2012).

27. BIS. Indian Standard Drinking Water Specification, Bureau of Indian Standards, IS 10500, (2012).

28. RadFard M, Seif M, Ghazizadeh Hashemi AH, MethodsX, 6,1021, (2019).

29. Acharya S, Sharma SK, Khandegar V.,Data Brief.18,2019,(2018).

30. Mallick J, Singh CK, AlMesfer MK, Water,10,1, (2018).

31. Selvakumar S, Chandrasekar N, Kumar G., Water Resour. Ind. 17,26, (2017).

32. Saraswat C, Kumar P, Dasgupta R, Avtar R, Bhalani P, Appl. Water Sci.9,1, (2019).

33. Annapoorani A, Murugesan A, Ramu A, Renganathan NG, Res. J. Chem. Sci. $4,99,(2014)$
34. Pradhan B, Open Hydrol. J. 4,51, (2011).

35. Sadashivaiah C, Ramakrishnaiah CR, Ranganna G, Int. J. Environ. Res. Public Health.5,158, (2008).

36. Gibbs RJ.American Association for the Advancement of Science.170,1088, (1970).

37. B Patil VB, Pinto SM, Govindaraju T, Hebbalu VS, Bhat V, Kannanur LN, Environ Geochem Health. 42, (2020).

38. Wilcox L v. Classification and Use of Irrigation Waters. Department of Agriculture, United States. (1955).

39. Zhang B, Song X, Zhang Y,Water Res.46,2737, (2012).

40. Balamurugan P, Kumar PS, Shankar K, Nagavinothini R, Vijayasurya, J. Chil. Chem. 